\title{
Impact of vat raise on Russian economy
}

\author{
Galina Semenova ${ }^{1,2, *}$ \\ ${ }^{1}$ Plekhanov Russian University of Economics, 36, Stremyanny lane, Moscow, 117997, Russia \\ ${ }^{2}$ Moscow Region State University, 24, Very Voloshinoy street, city of Mytishi, Moscow region, \\ 141014, Russia
}

\begin{abstract}
The entire taxation system works state-wise, being the primary source for the budget formation and treasury replenishment. Value added tax (VAT) plays a major role in the national economy. Thus, any manipulations on the tax will immediately affect the economy. VAT raise will adversely impact the economy and result in curbing the motivation of the society for entrepreneurial activity. Raise in the VAT rate may indirectly affect the collection of personal income taxes (PIT) and excise duties because of the higher pressure on the economy and escalation of inflation, lower effective demand and lower level of consumption due to rising prices. Tax novations may lead to serious consequences: increase in the tax burden, higher prices for the majority of goods and services, lower consumer demand, escalation of inflation, a worse situation in small and medium entrepreneurship, a slowdown in economic growth. Subject of the study is the value added taxation. Goal of the research is to prove the necessity and significance of the VAT hike. Methodology. The VAT rates in 2017 for European countries and Russia and indices of industrial production and business confidence were systematized.
\end{abstract}

\section{Introduction}

The Ministry of Finance suggested in spring 2017 to increase the basic rate of VAT in Russia to $22 \%$ as a part of a "tax maneuver". At same time, the premiums to extrabudgetary funds (pension, social and compulsory medical insurance funds) would be cut from $30 \%$ to $22 \%$ (to tackle the off-the-book wages); and the parallel VAT raise from $18 \%$ to $22 \%$ gave the name "22/22" to the maneuver. As a result, the basic rate became $20 \%$ in 2019 , while the preferential rate of $10 \%$ on food, children products, medicine and printed press was kept. This basic VAT rate was adopted in Russia from 1995 to 2004. As the Central Bank of Russia noted, "planned tax changes will increase inflation by about 1 percentage point" and appraised "annual inflation of 3.5-4\% at the end of 2018 and its short-term increase to $4-4.5 \%$ in 2019 . Consumer price growth will return to $4 \%$ at the beginning of 2020."

Value added tax, as a final consumption tax, currently exists in 162 countries around the globe. It was introduced around 50 years ago in Europe. The average basic rate of VAT is $21.5 \%$ for 28 countries of the EU. The VAT rate in Russia was $18 \%$ in 2017 (Fig. 1).

\footnotetext{
*Corresponding author: Sg6457@mail.ru
} 


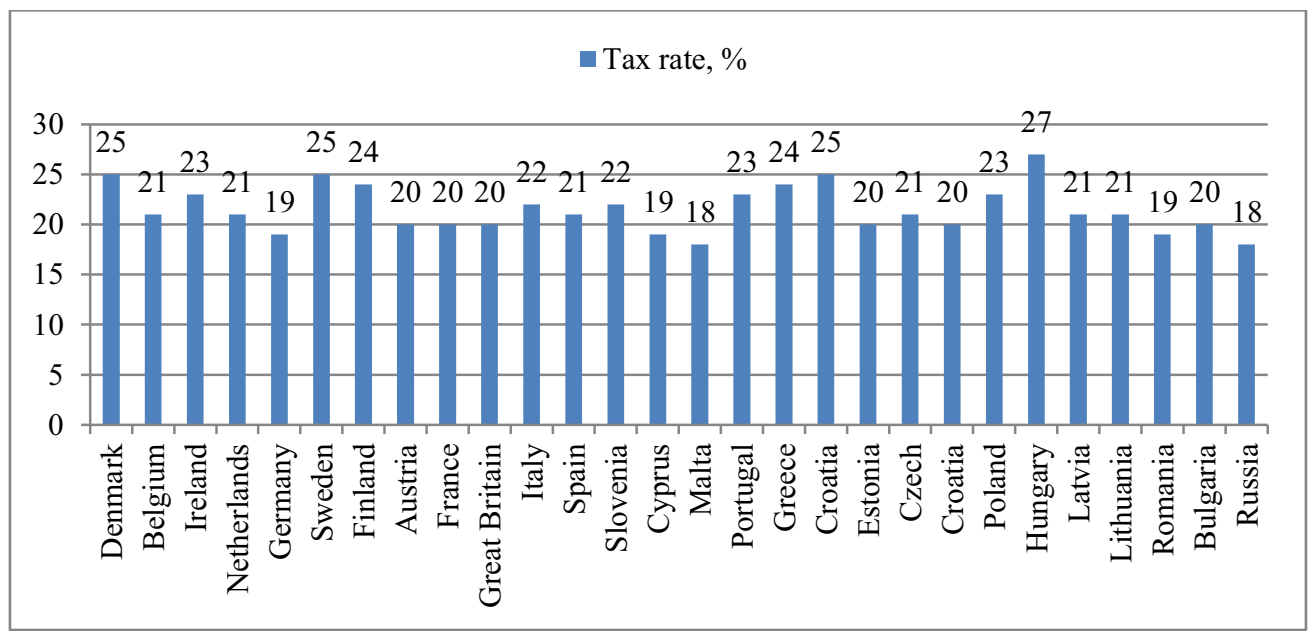

Fig. 1. VAT: Europe-Russia in 2017. Source: Taxes in the European Union http://42garmoniya.ru/nalogi-v-evrosojuze/.

VAT is not included, for instance, in estimation of the tax burden on a business since it does not have the same direct impact on the current revenue of the company as income taxes or wage bills.

\section{Materials and Methods}

VAT is the first most collectible tax in Russia. It is the largest budget revenue source despite oil and gas ones. This tax has been in implementation since 1992. Then the tax rate was maximum and amounted to $28 \%$. Later, the VAT rate went only down: it was reduced to $20 \%$ in 1993 , and became $18 \%$ in 2004 . In addition to VAT, sales tax of up to $5 \%$ was levied from 1998 to 2004. Starting January 1, 2019 the VAT rate was increased to 20\% $(+2 \%)[2]$.

Individual entrepreneurs and self-employed citizens will be the first to suffer. Raising VAT is a fairly simple move for the Russian government, which is forced to seek financing for the implementation of the new "May" decrees "On the national goals and strategic objectives of the Russian Federation through to 2024" of President of Russia Vladimir Putin.

This type of indirect tax is collected almost $100 \%$ in Russia, unlike other taxes. VAT is automatically shifted to consumers, defining the retail price [5]. A $2 \%$ hike is a huge turnover and a big burden for business. But rate of excise duties increases every January 1 , for example:

-motor car gasoline rate: as of January 1, 2018 - 11,239 rubles for 1 ton, July 1, 2018 11,892 rubles for 1 ton, January 1,2019 - 12314 rubles for 1 ton, January 1, $2020-12752$ rubles for 1 ton; [2]

-on diesel fuel: as of January 1, 2018 - 7,665 rubles for 1 ton, July 1, $2018-8,258$ rubles for 1 ton, January 1, $2019-8258$ rubles for 1 ton, January 1, 2020 - 8835 rubles. Increasing VAT and excise duties will result in higher prices for goods, work, services and freight transfer in Russia [2].

VAT hike mainly happened because of the loss of federal budget revenues due to lower oil prices. These revenues have always been the most important resource for the national budget. Oil prices fell below $\$ 40$ per barrel in March 2020, when they used to be $\$ 100-110$ in the beginning of 2014 . 
Tax receipts to the consolidated budget of the Russian Federation for 2017-2018 is shown in Fig. 2. There is an annual increase in tax revenues. The consolidated budget of Russia consists of: the federal budget, the budgets of the constituent entities of the Russian Federation and the budgets of municipalities. In 2018, the consolidated budget of the Russian Federation received revenues of 21329 billion rubles, or $22.9 \%$ more than in 2017, and in 2019 - 22503 billion rubles, or 5.5\% more than in 2018 .

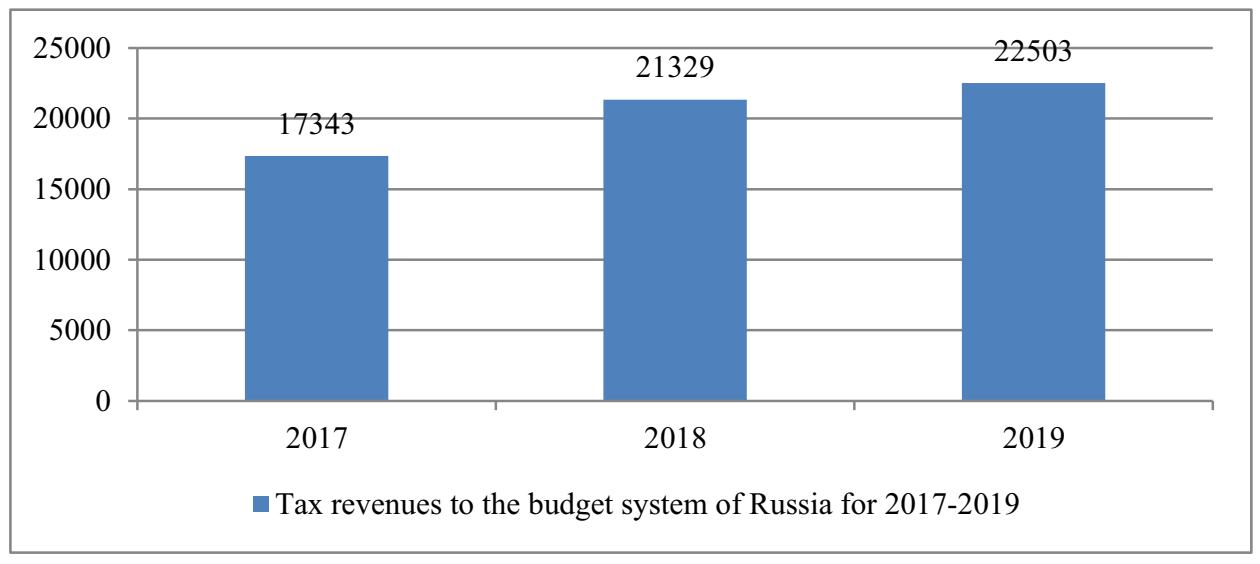

Fig. 2. Tax revenues to the budget system of Russia for 2017-2019 (Source: Source: Federal State Statistics Service

https://www.nalog.ru/rn50/related_activities/statistics_and_analytics/forms/6772396/, https://www.nalog.ru/rn50/related_activities/statistics_and_analytics/forms/7600100/, https://www.nalog.ru/rn50/related_activities/statistics_and_analytics/forms/8824368/).

Figure 3 shows the revenue structure of the consolidated budget of the Russian Federation in 2018-2019. 82\% of the budget in 2018 accrued to tax collection: mineral extraction taxes (MET) - 29\%, corporate income taxes - 19\%, VAT and personal income taxes (PIT) - 17\%.

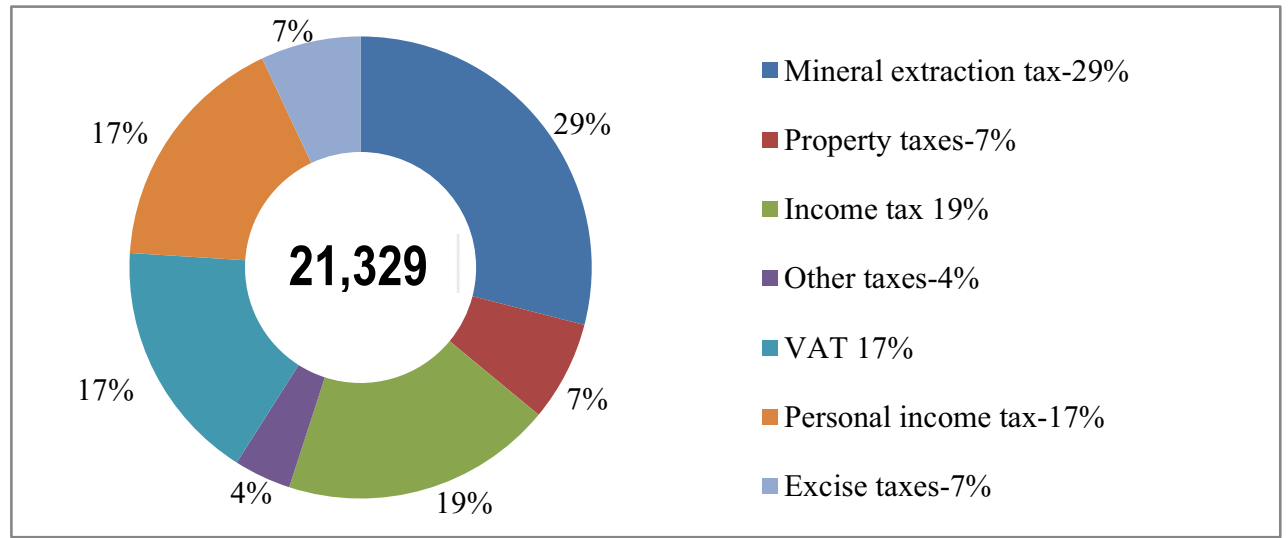

Fig. 3. Revenue structure of the consolidated budget of the Russian Federation in 2018, \% (Source: Source: Federal State Statistics Service https://www.nalog.ru/rn50/related_activities/statistics_and_analytics/forms/7600100/).

Collected taxes in 2019 accrued to $86 \%$ of the budget: MET $-28 \%$, corporate income taxes $-20 \%$, VAT $-20 \%$ and PIT $-18 \%$. Almost one third of the revenue in 2018-2019 is formed with mineral extraction taxes (MET) (Fig. 4). 


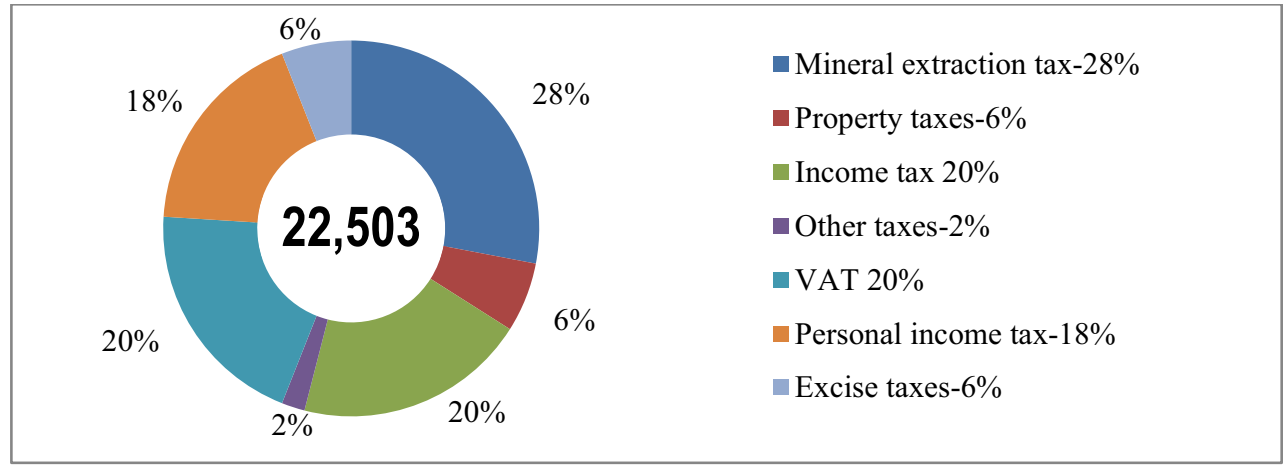

Fig. 4. Revenue structure of the consolidated budget of the Russian Federation in 2019, \% (Source: Source: Federal State Statistics Service https://www.nalog.ru/rn50/related_activities/statistics_and_analytics/forms/8824368/).

Currently, share of the petroleum economy is falling; non-oil, non-resource-based sectors are growing faster in Russia. The share of oil revenues in relation to GDP is slightly less. Thus, additional sources of income must be found to maintain the level of expenditures on infrastructure, education, and health service.

Therefore, VAT hike of $2 \%$ over 6 years should contribute about 2 trillion rubles to the budget to implement the "May" decrees of the President. So, according to the calculations of the Ministry of Finance of the Russian Federation, this measure will provide the federal budget with extra 633.5 billion rubles in 2019, in 2020 - 678 billion rubles, in $2021-728$ billion rubles.

In 2018, the federal budget received VAT in the amount of 3762 billion rubles, according to the Federal Tax Service of Russia, including: 3575 billion rubles were from goods, works and services sold in the Russian Federation and 187 billion rubles from the import. 4,258 billion rubles and 224 billion rubles respectively were collected in 2019 . The revenue growth amounted to $19.1 \%$ ( +720 billion rubles) [2].

What is good for the budget is not always good for the economy: forecasts for GDP growth in 2019 became worse after the VAT hike. In particular, the Ministry of Economic Development expects (.pdf) GDP to grow by only 1.6\% (estimate for: $2016-1.1 \%, 2017$ $1.5 \%, 2018-1.9 \%$ ) against the backdrop of a faster rise in prices and, as a result, a slowdown in consumer demand. According to the Research and Forecasting Department of the Central Bank of Russia, $1 \%$ of GDP collected by the State from VAT is a $0.75 \%$ decline in GDP. VAT hike will enhance the exaction of resources from the economy by $0.55 \%$ of GDP annually [1].

The major risks will fall on 2020. Then, receiving additional funds and starting to spend them should facilitate the GDP growth: The Ministry of Economic Development expects it to reach $3 \%$ by 2021 , but analysts are more skeptical in the context of the low potential growth of the economy.

\section{Results}

A large burden falls on small businesses with the raise of VAT rate of $2 \%$. It is predicted that with an increase in the tax burden, part of the business will be closed due to a shortage of funds, and the investments in the Russian economy will decrease. Higher rate may force foreign capital to leave Russia. The tax rate of $18 \%$ was considered the most optimal [4]. Industrial production declined due to the VAT hike. The data on the industrial production index in Russia are shown in Fig. 5. The index shows that the decline in industrial production occurred in May 2019 (-0.1), then it was growing till September 2019 (3.8), and 
then again declined to 0.7 in November 2019. Decrease in Purchasing Managers' index (PMI) is believed to be caused by the VAT raise in 2019.

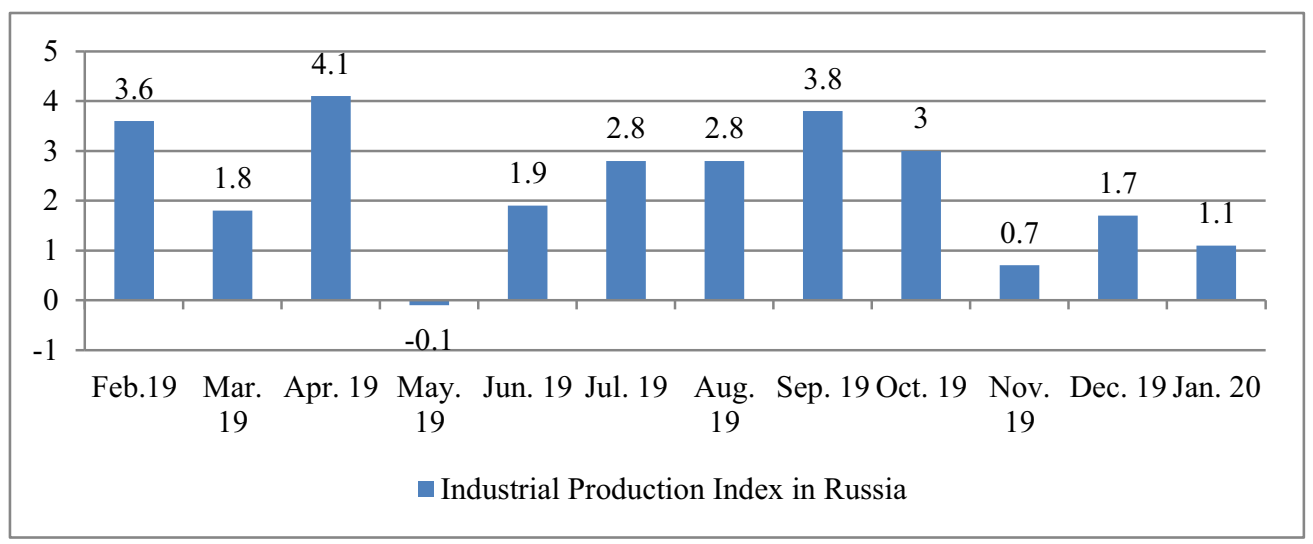

Fig. 5. Industrial Production Index in Russia (Source: Trading Economics https://ru.tradingeconomics.com/russia/business-confidence).

Figure 6 displays the data on the index of business confidence. This index contributes to investment activity, development of production and growth in employment.

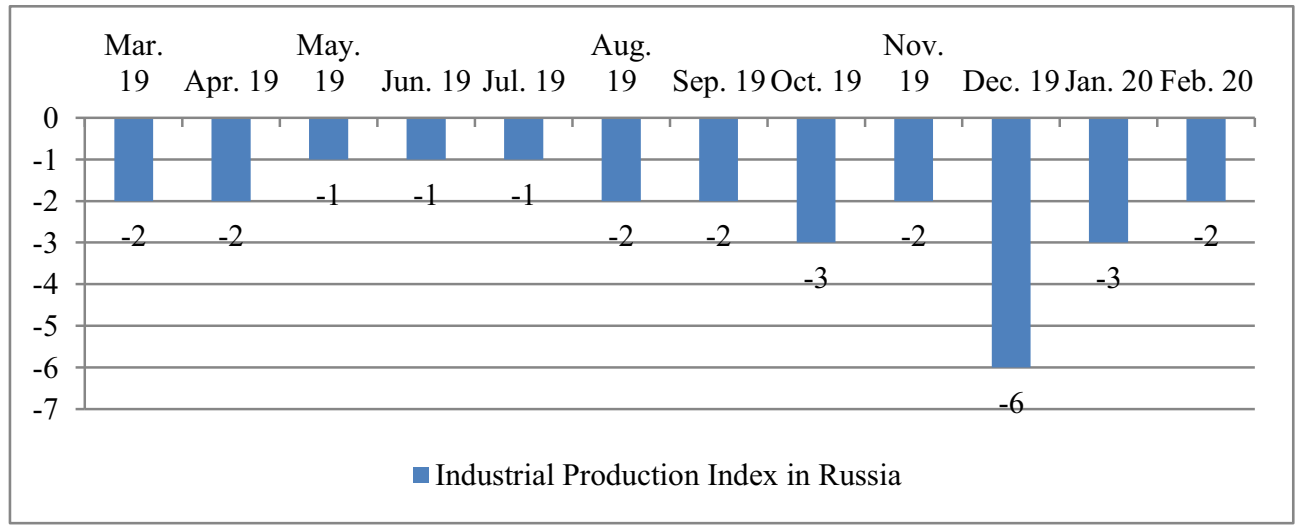

Fig. 6. Business Confidence Index in Russia (Source: Trading Economics https://ru.tradingeconomics.com/russia/business-confidence).

Dynamics of newly registered and dissolved legal entities in Russia for the period 20182019 (Table 1).

Table 1. Registration/dissolution of legal entities in Russia in 2018-2019 (Source: Federal Tax Service of Russia.https://www.nalog.ru/rn50/).

\begin{tabular}{|l|l|l|l|l|}
\hline \multicolumn{1}{|c|}{ Parameter } & $\mathbf{2 0 1 8}$ & $\mathbf{2 0 1 9}$ & $\begin{array}{c}\text { Ratio 2019 to } \\
\mathbf{2 0 1 8}, \\
+/-\end{array}$ & $\begin{array}{c}\text { Rate of } \\
\text { decline, \% }\end{array}$ \\
\hline Newly registered entities & 28,284 & 25,602 & $-2,682$ & 9.5 \\
\hline Dissolved entities & 62,830 & 53,506 & $-9,324$ & 14.2 \\
\hline
\end{tabular}

It is seen from table 1 that over two years the number of enterprises that ceased their activities decreased by almost 3.5 times (- 6642 entities) compared to the newly registered ones. But the number of newly registered enterprises decreased by $9.5 \%(-2,682$ entities $)$ in 2019 compared with 2018, while the number of dissolved businesses declined by $14.2 \%$ (- 
9,324 entities). The number of active enterprises in Russia and the number of employed personnel for the period 2018-2019 is presented in table 2 .

Table 2. Number of active enterprises in the Russian Federation and number of personnel in 20182019 (Source: Federal State Statistics Service. URL:https://www.gks.ru/).

\begin{tabular}{|l|l|l|l|l|}
\hline \multicolumn{1}{|c|}{ Parameter } & \multicolumn{1}{|c|}{$\mathbf{2 0 1 8}$} & \multicolumn{1}{|c|}{$\mathbf{2 0 1 9}$} & $\begin{array}{c}\text { Ratio 2019 to } \\
\mathbf{2 0 1 8},+/-\end{array}$ & $\begin{array}{c}\text { Rate of decline, } \\
\mathbf{\%}\end{array}$ \\
\hline $\begin{array}{l}\text { Number of active } \\
\text { enterprises }\end{array}$ & $3,433,533$ & $3,121,865$ & $-311,668$ & 9.1 \\
\hline Number of personnel & 82,559 & 60,017 & $-22,542$ & 27.3 \\
\hline
\end{tabular}

As it can be seen from table 2 , the number of active enterprises decreased by $9.1 \%$ ($311,668)$. This lead to $27.3 \%(-22,542)$ decrease in number of employees.

Approximately half of small and medium-sized enterprises dissolve in their first year. No more than $10 \%$ stay on the fly level. This pattern has become regular for the past few years and retains its negative trend. More than $90 \%$ of small and medium-sized enterprises are micro-businesses with the staff under 20 people. Tax conditions and tax rates for business are very important; especially from the point of view of stability [3]. The total tax burden on business $(47.4 \%)$ in Russia is 7.2 percentage points higher than the world average. Tax burden on the wage fund is 2.2 times higher than the global average.

\section{Discussion}

Hike in the VAT rate in Russia "will cause rise not only in consumer prices, but also in producer ones," notes Vera Kononova, Deputy Head of the Analytical Studies Department of the Institute for Complex Strategic Studies in Moscow. She also reminds: "The time lag between paying input VAT to suppliers when buying materials and receiving output VAT a product buyer in Russia can take months; this means diverting working assets of business for the respective term".

Raising the VAT rate will reduce profits [of business in Russia], which is already falling, adds Valery Mironov, Deputy Head of the Center of Development Institute of the Higher School of Economics. "If the task is to ramp up the economy, then raising taxes is a stupid decision," says Alexandra Suslina from the analytical center "Economic Expert Group". This is a blow to high-tech sectors that were already affected by the crisis, as well as to the poorest people, "Vedomosti" quotes Vladimir Salnikov, Deputy Head of the Center for Macroeconomic Analysis and Short-Term Forecasting.

Raising tax rates is always an additional incentive to drop off the radar. But it is highly unlikely in the case of VAT, RBC quotes opinion of Dmitry Kulikov, an expert of the research and forecasting group of the Analytical Credit Rating Agency (ACRA). He admits that authorities have chosen the right moment to raise VAT when the administration system is effective enough to avoid a noticeable decrease in tax collection.

\section{Conclusions}

Hike of the VAT rate up to $20 \%$ :

1. It will provide the state treasury with more than 600 billion rubles, which later will be used to fulfill the "May" decrees of President of Russia Vladimir Putin through 2024.

2. Escalation of inflation by $1.0-1.6 \%$ and a decrease in GDP by $0.22-0.36 \%$, investments by $0.5-0.6 \%$, and exports are anticipated. A higher inflation rate in 2019 , than it is expected, will adversely affect the cost of products and services. 
3. Given the rise in prices, the consumer market will decline, and the income of entrepreneurship will decrease. There are two options for vendors to tackle the problem: cut the number of purchases or operate at a loss.

4. Rise in the cost of gasoline with directly affect the supply and sale prices.

5. The level of exports will decrease, because imported products will be unprofitable to sell.

An increase in the tax burden will inevitably "blow" on many sectors focused on domestic demand, for example, construction, manufacturing, small and medium-sized enterprises, which are experiencing a hard time in the current economic situation.

\section{References}

1. V. Artemyeva, Young scientist 45, 51-53 (2018) https://moluch.ru/archive/231/53621/

2. G. Semenova, Economics and management: problems, solutions 2(12), 37-42 (2018) https://www.elibrary.ru/item.asp?id=36552564

3. G. Semenova, Bulletin of Moscow State Regional University 1, 233-237 (2011) https://www.elibrary.ru/item.asp?id=21211400

4. G. Semenova, E3S Web of Conferences, TPACEE-2018 91, 08047 (2019) DOI: $10.1051 / \mathrm{e} 3$ sconf $/ 20199108047$

5. The Russian Union of Industrialists and Entrepreneurs of Russia, http://xn--o1aabe.xn-p1ai/ 